\title{
Lack of Repair of Rat Skull Critical Size Defect Treated with Bovine Morphometric Protein Bound to Microgranular Bioabsorbable Hydroxyapatite
}

\author{
Gabriel Ramalho FERREIRA \\ Tania Mary CESTARI \\ José Mauro GRANJEIRO \\ Rumio TAGA \\ Department of Biological Sciences, Faculty of Dentistry of Bauru, University of São Paulo, Bauru, SP, Brazil
}

\begin{abstract}
The ability of a pool of bovine bone morphogenetic proteins bound to synthetic microgranular hydroxyapatite (BMPb-HA) to stimulate bone repair was determined in rat critical size defects. An 8-mm diameter defect was created in the calvaria of 25 rats. In 15 rats, the defects were filled with $\mathrm{BMPb}-\mathrm{HA}$ homogenized with blood (experimental group), and in 10 rats the defects were filled only with blood clots (control). The calvariae of experimental rats were collected 1, 3 and 6 months after surgery and of the control rats at the end of surgery and 6 months thereafter. The morphometric results obtained in the radiographs showed an absence of new bone formation at 1 and 3 months post-surgery and, histologically, the defects were filled with fibrous connective tissue and numerous foci of a foreign body-type granulomatous reaction around hydroxyapatite agglomerates. At the end of 6 months, the number and size of the granulomatous foci decreased and the area of the defects was reduced by $22 \%$ compared to the 0 -hour control due to the formation of new bone at their borders, although the mean area was similar to the 6-month control. We conclude that the use of BMPb-HA in the treatment of critical size bone defects of the rat skull leads to the formation of a foreign body-type granulomatous reaction that markedly inhibits new bone formation, suggesting that synthetic microgranular hydroxyapatite does not represent a good carrier for BMPinduced bone formation.
\end{abstract}

Key Words: bovine BMP, hydroxyapatite, bone repair, critical size, skull.

\section{INTRODUCTION}

In the mid-1960s, the orthopedist and scientist Dr. Marshall R. Urist showed that the devitalized and demineralized bone matrix of rabbit exhibited a high capacity to induce the formation of new bone inside the thigh muscle of another rabbit, thus discovering the phenomenon of osteoinduction (1). Subsequent studies have demonstrated that this inductive capacity was due to water-insoluble protein factors present in the organic bone matrix (2).

In 1984, Urist (3) and collaborators isolated in pure form a low molecular weight protein from bovine bone matrix that showed a high inductive capacity of osteoblast differentiation and, consequently, osteogenesis at heterotopic sites when reconstituted with inac- tive collagen matrix. This protein, due to its ability to induce undifferentiated mesenchymal cells to differentiate into osteogenic cells, was called bone morphogenetic protein (BMP). Based on this study, other researchers have reported the isolation and purification of other bovine bone proteins showing osteoinductive capacity $(4,5)$. Subsequent improvements in genetic recombination techniques have led to the production and characterization of eight types of BMP present in human bone matrix.

All studies carried out with native, bovine and human BMPs in their pure or semipurified form and with recombinant human BMP have shown a high capacity of these proteins to induce the repair of perennial bone defects in different animals (6-8). With respect to its clinical use, Sailer and Kolb $(9,10)$ reported

Correspondence: Dr. Rumio Taga, Departamento de Ciências Biológicas - Histologia, Faculdade de Odontologia de Bauru, USP, Al. Dr. Octávio Pinheiro Brisolla, 9-75, Vila Universitária, 17012-901 Bauru, SP, Brasil. Tel: +55-14-3235-8259 or +55-14-3235-8274. e-mail: cestari@fob.usp.br 
the successful application of bovine BMP for the treatment of hundreds of patients with extensive bone defects in the face and skull.

In the present study, we determined the ability of a commercial bovine BMP product bound to synthetic microgranular hydroxyapatite (BMPb-HA) to stimulate the repair of critical size bone defects produced with a surgical trephine in the rat skull.

\section{MATERIAL AND METHODS}

Twenty-five male albino rats, aged 100 days and weighing about $250 \mathrm{~g}$, were obtained from the Central Animal House of the Bauru Dental School. The animals received Purina pellet ration and water ad libitum throughout the experiment.

The rats were divided into the following groups: a) an experimental group consisting of 15 animals which were sacrificed in subgroups of 5 animals each at 1, 3 and 6 months after surgery, b) a 0-hour control group consisting of 5 animals, and c) a 6-month control group consisting of 5 animals.

\section{Test Material}

Bone morphogenetic proteins (Ministry of Health approval \#103.455.00003) are proteins of low molecular weight, predominantly around 14000 to 30000 daltons obtained from the bovine fetal cortical bone. The protein is adsorbed to microgranular hydroxyapatite (mean particle size of $5 \mu \mathrm{m}$ ) prepared from chemical reaction between calcium chloride $\left(\mathrm{CaCl}_{2}\right)$ and sodium phosphate $\left(\mathrm{Na}_{2} \mathrm{HPO}_{4}\right)$ with a posterior thermal treatment with sodium hydroxide and phosphate buffer.

\section{Surgical Procedures}

All animals were anesthetized by intramuscular injection of xylazine/ketamine (Agribrands do Brasil Ltda, Paulínea, SP, Brazil) and submitted to trichotomy of the frontoparietal region of the head, vigorous disinfection with iodophor alcohol, and isolation of the surgical area. An incision in the shape of a half-moon was then made in the skin of the skull with a \#10 surgical knife and the flap was raised backwards with a Molt spatula, thus widely exposing the cranial bone surface of the region. Using a surgical trephine measuring $8 \mathrm{~mm}$ in nominal diameter, a central perforation was created in the parietal bone under abundant and continuous irrigation with physiological saline, crossing the entire diploë and exposing the dura-mater at the fundus of the defect. Immediately after opening, the defect was filled with $60 \mathrm{mg}$ blood-agglutinated BMPbHA (Gen-Pro ${ }^{\mathrm{TM}}$, Baumer, Mogi Mirin, SP, Brazil) in experimental animals, while in control animals the defect was only filled with blood clots. The flap was then placed in position and closed with \#4 nylon sutures (Ethicon, Johnson \& Johnson, São José dos Campos, SP, Brazil).

\section{Radiographic and Histologic Procedures}

Experimental animals were sacrificed by injection of an overdose of the anesthetic 1, 3 and 6 months after surgery, while control animals were sacrificed immediately and 6 months after surgery. The skullcap of each animal with overlying skin was removed with an electric saw and immediately placed in $10 \%$ formalin in phosphate buffer, $\mathrm{pH}$ 7.3. After fixation for one week, the specimens were radiographed at the Laboratory of Radiology, Department of Stomatology, Bauru Dental School, and demineralized in Morse solution (50\% formic acid $+20 \%$ sodium citrate, $1: 1)$ for a period of about 40 days. The specimens were then washed under running water overnight, dehydrated in ethanol, cleared in xylene and embedded in Histosec (paraffin + synthetic resin, Merck KGaA, Darmstadt, Germany). The specimens were cut in the laterolateral direction into alternating $5-\mu \mathrm{m}$ thick sections and stained with hematoxylin-eosin.

\section{Morphometric Analysis of the Radiographic Images}

Using a Hewlett Packard ScanJet 4C/T scanner, the radiographic images were standardized (300 dpi of resolution with equal brightness and contrast) and transferred to a digitized image analysis system consisting of the Kontron KS 300 software (Kontron Electronic $\mathrm{GmbH}$, Zeiss, Munich, Germany) installed on an IBM computer. The initial area of the lesion (Ai) was determined in the 0-hour control group and the area without new bone formation (A) was measured in the other groups. The area of each defect filled with newly formed bone (Aon) was calculated by the equation Aon $=$ Ai-A. 


\section{Histologic Analysis}

All histologic sections were blindly analyzed by a single calibrated observer with an Olympus $\mathrm{CH} 2$ binocular microscope (Olympus Optical Co. Ltd., Tokyo, Japan) and the following events were determined: presence of inflammatory infiltrates, intensity of angiogenesis, presence of granulation tissue, resorption of the biomaterial, reorganization of the periosteum, and occurrence of new bone formation. The photographs were obtained under a Zeiss-Axioskop photomicroscope (Carl Zeiss Jena GmbH, Jena, Germany).

\section{Statistical Analysis}

The morphometric results were compared between groups by analysis of variance (ANOVA) and a pairwise multiple comparison test (Student-Newman-Keuls test) using the Sigma Stat software for Windows (Jandel Scientific), with the level of significance set at $5 \%$.

\section{RESULTS}

We noted during surgery that agglutination of $\mathrm{BMPb}-\mathrm{HA}$ with the animal's own blood prevented blood coagulation. Surgical follow-up showed no external signs of infection in the surgical region in any of the animals. Some animals presented slight edema which disappeared a few days later without the occurrence of suppuration and/or opening of the incision.

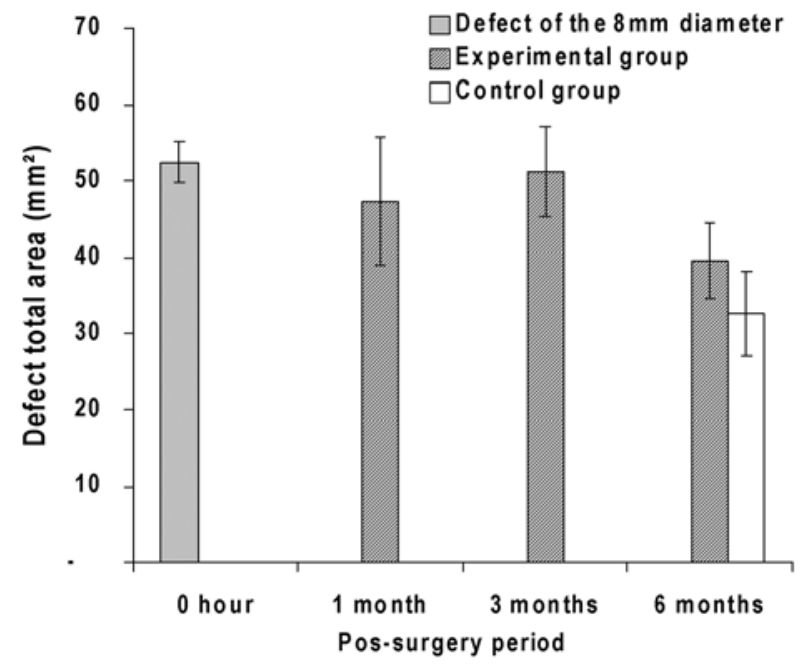

Figure 1. Area of bone defect $\left(\mathrm{mm}^{2}\right)$ obtained in the radiographic images. Mean \pm SEM of 5 animals

\section{Radiographic and Morphometric Results}

The radiographic image measurements of the defect in the different groups are shown in Figure 1.

In the 0 -hour control group, the mean area of the defects was $52.5 \mathrm{~mm}^{2}$. In the 1-month and 3-month experimental groups, the mean area of the defects was 47.3 and $51.3 \mathrm{~mm}^{2}$, respectively, with no difference compared to the 0 -hour control group $(\mathrm{P}>0.05)$. Six months after surgery, the defects showed a $22 \%$ reduction in size compared to the 0 -hour control group $(\mathrm{P}<0.05)$ as demonstrable by an increase in the radiodense area at the border of the defect. However, no significant difference $(\mathrm{P}>0.05)$ in mean area was observed between the 6-month treated group (area $=39.5$ $\left.\mathrm{mm}^{2}\right)$ and the 6-month control group $\left(\right.$ area $\left.=32.6 \mathrm{~mm}^{2}\right)$.

\section{Morphologic Results}

Six-month control group: The border of the defects showed a small amount of new bone tissue and their opening was found to be filled with dense connective tissue rich in fibroblasts and blood vessels in all animals of the group. Occasionally, bone islets formed by interstitial osteogenesis were observed in fibrous connective tissue.

Experimental group: At 1 month after surgery, the space of the defect was found to be filled with fibrous connective tissue and numerous foci of a foreign body-type granulomatous inflammatory reaction characterized by epithelioid macrophages, some of them fused, surrounded by a chain of mononuclear leukocytes (Figure 2A and B). In some cases, agglomerates of needle-shaped hydroxyapatite particles were observed inside the granuloma (Figure 2C) and in some cases weak osteogenesis was noted in the epidural region of the border of the defect (Figure 2A).

The 3-month treated group showed a histologic picture similar to that of the previous group.

After 6 months of treatment, we observed a reduction in the number and size of the granulomatous reaction foci in connective tissue and significant bone neoformation at the border of the defects (Figure 2D).

\section{DISCUSSION}

BMPs are members of the TGF- $\beta$ superfamily and regulate the growth, differentiation and apoptosis 

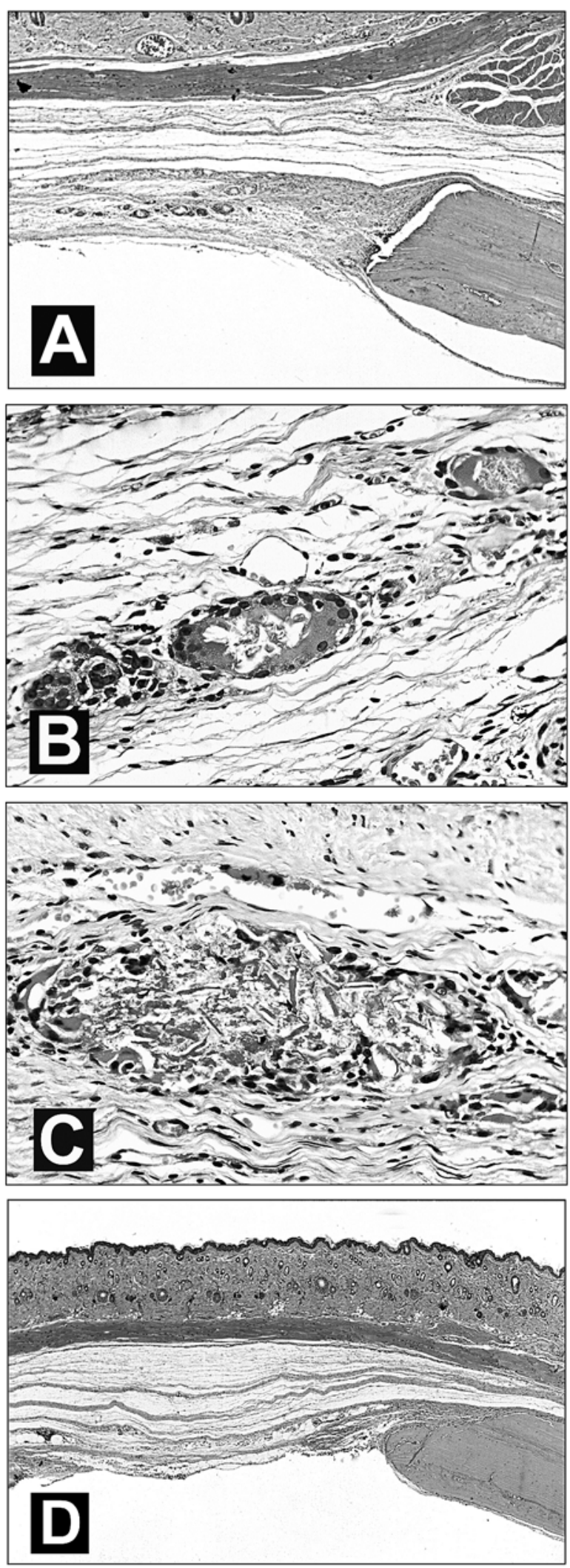

of various cell types such as osteoblasts, chondroblasts, and neural and epithelial cells during the period of development (11). These proteins, initially identified in organic bone matrix and characterized by their high capacity to induce new bone formation at heterotopic sites, have been suggested as a promising alternative in the stimulation of repair of bone lesions and the regeneration of lost periodontal tissue (12).

In this respect, numerous experimental studies conducted on different animal species have demonstrated that pure or semipurified BMPs extracted from bovine bone possess a high capacity to stimulate bone formation and, thus, to promote the repair of various types of perennial bone defects $(6,7)$. Clinical studies conducted on humans using this xenogenic BMP also yielded very positive results $(9,10)$. It should be noted that the use of BMP extracted from bovine bone in the treatment of human perennial bone defects is based on the chemical homology, demonstrated by DNA cloning, between human and bovine BMPs $(9,10,13)$.

In the present study, the osteogenic potential of a pool of bovine BMPs bound to synthetic microgranular hydroxyapatite was determined for a critical size bone defect produced surgically in the rat skull. In contrast to the studies cited above, the present results did not show significant formation of new bone 6 months after surgery compared to the respective control group, findings similar to those reported by da Costa et al. (14) for rabbit bone marrow using crude bovine BMP bound to the same type of carrier mixed with inorganic bovine bone.

The negative results obtained here call attention to the finding that $\mathrm{BMPb}-\mathrm{HA}$ prevented blood coagulation during blood agglutination for filling the defect and even promoted the dissolution of preformed blood clots, a fact that might have impaired the maintenance of sufficient amounts of the material inside the defect. However, histologic analysis showed no significant quantity of the material in tissues surrounding the de-

Figure 2. Experimental group. A-C: 1 month after surgery: A) defect filled with fibrous connective tissue and foci of a foreign body-type granuloma; B) detail of foreign body-type granuloma, and C) agglomerates of needle-shaped hydroxyapatite particles. D) 6 months after surgery, small bone neoformation at the border of the defects and fulfilment by fibrous conective tissue. Hematoxylin-eosin, magnification $34 \mathrm{X}$ and $340 \mathrm{X}$. 
fect.

We emphasize that semipurified fractions of BMPs like those used here may contain, depending on the grade of purification, other non-collagenous bone proteins able to cause an immunologic reaction that inhibits new bone formation, or even osteogenesisinhibiting proteins (14). Sampath and Reddi (15) have suggested that non-collagenous bone proteins with a molecular mass above 50,000 Da might represent immunogenic components of the bone matrix. However, no significant numbers of lymphocytes or plasma cells were observed in the area of the defect during any of the periods studied.

In addition, the defects of animals treated with $\mathrm{BMPb}-\mathrm{HA}$ were found to be filled with fibrous connective tissue during all periods studied, with this tissue containing numerous granulomatous reaction foci, especially at 1 and 3 months of treatment, characterized by large accumulation of epithelioid macrophages, some of them fused, surrounded by lymphocytes, and accompanied by the presence or absence of hydroxyapatite crystals inside the defect.

In a previous study from our laboratory in which perennial bone defects in the guinea pig skull were treated with a mixture of lyophilized bovine bone matrix and the same synthetic microgranular hydroxyapatite as used here, we observed in the group in which the defect was not covered with a reabsorbable membrane that the hydroxyapatite particles normally absorbed by macrophages showed a tendency toward agglomeration and the formation of larger bodies. This reduced the surface of the area and impaired resorption, a fact leading to the formation of a foreign body-type granulomatous reaction with the presence of large numbers of macrophages and giant cells. We inferred that this generated a favorable environment for the formation of fibrous tissue and the blockade of new bone formation (16). Similar results were observed by Brandão et al. (17) in rat alveoli treated with BMPb-HA after dental extraction.

In this respect, other studies using larger nonreabsorbable porous hydroxyapatite (Interpore 200) combined with demineralized bone matrix have shown that these larger particles produce a local foreign bodytype reaction, increasing the formation of fibrous tissue and markedly reducing new bone formation (18). Probably, the histologic picture observed in the present study, similar to the findings reported in the investiga- tions cited above, was the main factor responsible for the almost complete blockade of new bone formation demonstrated mainly after 1 and 3 months of treatment.

Recent studies have demonstrated the importance of the physicochemical and structural characteristics of the BMP carrier in the expression of the inductive activity of these proteins. The carrier should be physicochemically biocompatible, permit cell adhesion and have affinity for biomolecules, and should structurally exhibit a geometry with adequate porosity and inter-pore connections in order to facilitate cell migration and angiogenesis, in addition to serving as a bed for BMP-induced new bone formation $(19,20)$.

The importance of the geometrical properties of the carrier has been demonstrated in two studies by Kuboki and collaborators $(19,20)$. In the first study, a pool of bovine BMPs was bound to two porous hydroxyapatite carriers, one consisting of coral and the other being a synthetic hydroxyapatite, and to a hydroxyapatite carrier consisting of solid particles. The authors observed large bone formation in the porous material, while formation of fibrous tissue occurred around the solid particles. In the second study, recombinant and bovine BMPs were combined with porous particles or blocks of hydroxyapatite or with fibrous glass membrane. The authors noted that the geometry of the carrier controlled the phenotypic expression of osteogenesis and chondrogenesis, i.e., BMPs carried by porous hydroxyapatite induced the direct formation of bone tissue without passing through the cartilage stage, while BMPs carried on fibrous glass membrane stimulated only cartilage formation.

The present results permit us to conclude that the use of a pool of bovine BMPs combined with microgranular hydroxyapatite in the treatment of critical size bone defects in the rat skull leads to the formation of numerous agglomerates of hydroxyapatite particles which promote a foreign body-type granulomatous reaction that markedly inhibits new bone formation. These findings suggest that this type of synthetic hydroxyapatite ceramic does not represent a good carrier for BMP-induced bone formation.

\section{RESUMO}

A capacidade de um pool de proteínas morfogenéticas bovinas ligada a hidroxiapatita sintética absorvível microgranular(BMPbHA) em estimular a reparação óssea foi avaliada em defeito de tamanho crítico em calvária de rato. Defeitos de $8 \mathrm{~mm}$ diâmetro 
foi produzido na calvária de 25 ratos, sendo 15 preenchidos com $\mathrm{BMPb}-\mathrm{HA}$ homogeinizado com sangue (grupo experimental) e 10 somente com coágulo sanguíneo (grupo controle). As calvárias dos animais do grupo experimental foram coletadas 1,3 e 6 meses após as cirurgias e as do grupo controle, ao término da cirurgia e após 6 meses. Os resultados morfométricos obtidos nas imagens radiográficas apresentou ausência de formação óssea nos períodos de 1 e 3 meses e, histologicamente os defeitos estavam preenchidos por tecido conjuntivo fibroso e inúmeros focos de reação granulomatosa, tipo corpo estranho, ao redor de aglomerados de hidroxiapatita. Ao final de 6 meses, os focos de reação granulomatosa diminuiu em número e tamanho e os defeitos diminuíram a sua área em $22 \%$ em relação ao controle 0 hora, devido a neoformação óssea nas suas bordas, mas apresentaram área semelhante ao controle 6 meses. Concluímos que a utilização de BMPb-HA no tratamento de defeitos ósseos cranianos em ratos, promove a formação de reação granulomatosa tipo corpo estranho que inibe profundamente a neoformação óssea, sugerindo que a hidroxiapatita sintética microgranular não é um bom carreador para as BMPs expressarem o seu potencial indutor.

\section{REFERENCES}

1. Urist MR. Bone: formation by autoinduction. Science 1965;12:150:893-899.

2. Reddi AH, Anderson WA. Collagenous bone matrix-induced endochondral ossification hemopoiesis. J Cell Biol 1976;69:557572 .

3. Urist MR, Huo YK, Brownell AG, Hohl WM, Buyske J, Lietze A, Tempst P, Hunkapiller M, DeLange RJ. Purification of bovine bone morphogenetic protein by hydroxyapatite chromatography. Proc Natl Acad Sci USA 1984;81:371-375.

4. Luyten FP, Cunningham NS, Ma S, Muthukumaran N, Hammonds RG, Nevins WB, Woods WI, Reddi AH. Purification and partial amino acid sequence of osteogenin, a protein initiating bone differentiation. J Biol Chem 1989;264:13377-13380.

5. Bentz H, Nathan RM, Rosen DM, Armstrong RM, Thompson AY, Segarini PR, Mathews MC, Dasch JR, Piez KA, Seyedin SM. Purification and characterization of a unique osteoinductive factor bovine bone. J Biol Chem 1989;264:20805-20810.

6. Sciadini MF, Dawson JM, Johnson KD. Bovine-derived bone protein as a bone graft substitute in a canine segmental defect model. J Orthop Trauma 1997;11:496-508.

7. Asahina I, Watanabe M, Sakurai N, Mori M, Enomoto S. Repair of bone defect in primate mandible using a bone morphogenetic protein (BMP)-hydroxyapatite-collagen composite. J Med Dent
Sci 1997;44:63-70.

8. Boyne PJ. Application of bone morphogenetic proteins in the treatment of clinical oral and maxillofacial osseous defects. J Bone Joint Surg Am 2001;83-A Suppl 1(Pt 2):S146-150.

9. Sailer HF, Kolb E. Application of purified bone morphogenetic protein (BMP) preparations in cranio-maxillo-facial surgery. Reconstruction in craniofacial malformations and post-traumatic or operative defects of the skull with lyophilized cartilage and BMP. J Craniomaxillofac Surg 1994;22:191-199.

10. Sailer HF, Kolb E. Application of purified bone morphogenetic protein (BMP) in cranio-maxillo-facial surgery. BMP in compromised surgical reconstructions using titanium implants. J Craniomaxillofac Surg 1994;22:2-11.

11. Sakou T. Bone morphogenetic proteins: from basic studies to clinical approaches. Bone 1998;22:591-603.

12. Hoffmann A, Weich HÁ, Gross G, Hillmann G. Perspectives in the biological function, the technical and therapeutic application of bone morphogenetic proteins. Appl Microbiol Biotechnol 2001;57:294-308.

13. Ripamonti U, Reddi AH. Periodontal regeneration: potential role of bone morphogenetic proteins. J Periodontal Res 1994;29:225235.

14. da Costa Filho LC, Taga R, Taga EM. Rabbit bone marrow response to bovine osteoinductive proteins and anorganic bovine bone. Int J Oral Maxillofac Implants 2001;16:799-808.

15. Sampath TK, Reddi AH. Homology of bone-inductive proteins from human, monkey, bovine, and rat extracellular matrix. Proc Natl Acad Sci USA 1983;80:6591-6595.

16. Taga R, Cestari TM, Taga EM, Assis GF, Marine MG. Avaliação histológica, radiográfica e morfométrica da reparação de defeito ósseo perene em crânio de cobaia tratado com mistura de Osseobond e Biohapatita e membrana absorvível de cortical óssea bovina. J Brasileiro Endo Perio 2000;1:78-87.

17. Brandão AC, Brentegani LG, Novaes Junior AB, Grisi MF, Souza SL, Taba Junior M, Salata LA. Histomorphometric analysis of rat alveolar wound healing with hydroxyapatite alone or associated to BMPs. Braz Dent J 2002;13:147-154.

18. Lindholm TC, Gao TJ, Lindholm TS. Granular hydroxyapatite and allogeneic demineralized bone matrix in rabbit skull defect augmentation. Ann Chir Gynaecol Suppl 1993;207:91-98.

19. Kuboki Y, Takita H, Kobayashi D, Tsuruga E, Inoue M, Murata M, Nagai N, Dohi H, Ohgushi H. BMP-induced osteogenesis on the surface of hydroxyapatite with geometrically feasible and nonfeasible structures: topology of osteogenesis. J Biomed Mater Res 1998;39:190-199.

20. Kuboki Y, Jin Q, Takita H. Geometry of carriers controlling phenotypic expression in BMP-induced osteogenesis and condrogenesis. J Bone Joint Surg Am 2001;83-A Suppl 1(Pt2):S105-115. 